\title{
Development of Marketing Learning to Improve Social Skills Based on Information Technology at Community Learning Center
}

\author{
Rita Aryani \\ \{ritaar1757@gmail.com\} \\ Sekolah Tinggi Keguruan dan Ilmu Pendidikan (STKIP) Panca Sakti, Bekasi Jawa Barat, Indonesia
}

\begin{abstract}
Marketing learning is a teaching and learning process that occurs from a business activity that is designed to plan, determine costs, promotion, and distribution of goods so that it reaches the consumer. The development of information technology can be used as a tool used in the teaching and learning process. The purpose of this research is to find and develop marketing learning in improving one's skills in study groups. The research method used is the Research \& Development (Research \& Development) method, and data analysis uses a Qualitative approach and literature review that utilizes all the information needed. The results to be achieved are all members who are members of the learning center are expected to increase their skills in marketing to take advantage of internet technology.
\end{abstract}

Keywords: Information Technology, Marketing Learning, Social Skills.

\section{Introduction}

Marketing Learning is a process of exchanging knowledge from those who give material to those who receive material in a system of business activities that are designed to plan and determine prices, promote, and distribute products that can satisfy the desires and services of both current and potential consumers to reach the target market and the goals of the agency that owns the business. Teaching and Learning Center is an institution formed by the community for people engaged in education which is still under the supervision and guidance of the Office of National Education [1]-[4]. This institution can be in the form of village or sub-district level. The surrounding environment is a potential that can be used to support community activities in the learning process (1) about the national education system which states that curriculum development (2) carried out by referring to national education standards and curricula at all levels and types of education developed with the principle of correction in accordance with the education unit, local potential, and the community so that the development of learning processes in the surrounding environment needs to refer to local potential in an area. Learning Development as a systematic way to identify, develop, and evaluate a set of learning materials and strategies with the aim of achieving certain goals. This needs to be done to get a model that is suitable for use and applied in their respective institutions. This development can be done in a variety of existing educational institutions, ranging from community learning groups to universities [5]-[7]. Learning in the surrounding environment has an important role in conveying knowledge (3) to the community so we need a 
media that contains information and ideas that can facilitate community learning (4). Learning resources are not only obtained from teachers and books that are theoretical but can also be obtained from the surrounding environment. The learning development model is actually made according to needs but in general can be divided into several steps to improve skills (5). Steps that can be carried out are: Identification of goals (institutional goals to be adjusted to educational goals), instructional analysis, identification of initial behaviors, Formulating goals, developing benchmark reference tests, developing teaching strategies, developing or choosing teaching, designing and carrying out formative evaluations, writing tools, and teaching division. Social skills are the ability of individuals to communicate effectively $(6,7)$ with others both verbally and nonverbally according to the situation and conditions at the time, where these skills are learned behavior [8]-[10]. "Social skills are the ability of one or a community member to establish relationships with others and their ability to solve problems with which a harmonious society can be achieved"(8). Information Technology is a general term for a study of design, implementation, development, support or management of computer-based information systems, especially hardware and software that is carried out to assist humans in making, changing, storing, communicating and/or spread information. In general Information Technology integrates high-speed computing and communication for data, voice, and video [11], [12]. Examples of Information Technology include not only personal computers, but also telephones, TVs, electronic household appliances, and modern handheld devices. The development of this technology can be utilized as a supporting device that can be used to make it easier to achieve the goals to be achieved. Marketing learning is one of the fields of science that requires technological support in distributing information to be delivered because the information to be conveyed can be in the form of text, moving and still images, sounds, animations, and others. And local decision making can be processed in modules based on local potential. In the local module using the presence or absence of potential used as learning (9). Local potential found in the environment can be used as a means and infrastructure in the process and can improve social skills [13]-[15].

There are several main objectives to be achieved in this research, namely: providing the broadest possible knowledge and opportunities for people who have obstacles to improve the quality of the business carried out, opening skills education opportunities, as well as guiding to have a life skill that is expected to later function to gain job access or your own business, so you can be independent in your life.

The center of teaching and learning activities that exist in community groups is nonformal educational institutions that are built by the community themselves with specific objectives, for example, for people who already have a business and have problems in distributing their business products, then this teaching and learning center was formed as a place for gathering the whole community in sharing marketing knowledge. This is because the community has different educational backgrounds and business experiences, so it is hoped that marketing communication can be more beneficial supported by advances in information technology. To achieve the desired goals, there are several ways that will be taken, among others: to record the entire community around the central location of teaching and learning activities, then formulate goals and targets to be achieved, conduct business data collection using technology, establish a management center for teaching and learning activities and determine learning model and time in carrying out these activities [5]-[8], [16], [17]. 


\section{Research Method}

This research was designed using research and development methods, while the data analysis was with a qualitative approach. To determine the effectiveness of the model, QuasiExperiment (Quasy Experiment) is used, using the "One Group Pretest-Posttest Design" model [18]-[20]. Data collection uses observation techniques that are carried out by certain procedures and rules so that observation provides space for scientific interpretation. Besides, researchers analyze with a deductive analysis that describes general events and then collect them with special characteristics. The location used as research is the Johor Baru Teaching and Learning Center, Central Jakarta. The research subjects consisted of one manager, two tutors, and 27 learners.

\section{Result and Discussion}

Marketing learning can be interpreted as a social process that makes individuals or groups meet the needs and desires through mutual exchange. The marketing learning process is basically the interaction between students and prospective object buyers, the times, and processes and products. The marketing concept defines the key to achieving organizational goals consists of determining the needs and desires of the target market and providing the expected satisfaction more effectively and efficiently than competitors. In marketing learning in society, there are not many contextual gaps in symptoms and problems, and the language used does not make improper interpretations so the meaning that is trying to be expressed is not appropriate. In this case, if there are symptoms / new / other problems that arise, there is an understanding of the experiences experienced by students. Given that the reasoning process is basically a mental process of forming a system of understanding through multirepresentation, which can support arguments, explanations, and predictions. In this process, dynamic practices are needed as a bridge to facilitate the interpretation of the symptoms of marketing problems. That is, the text will be better if combined and interact with other forms of expression of meaning in an effort to get more comprehensive.

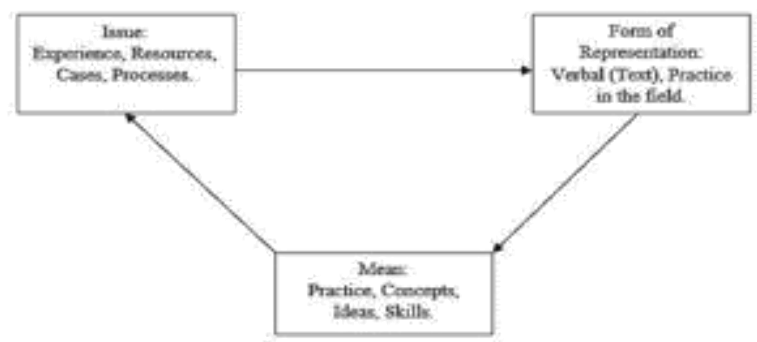

Fig. 1. Triadic model of multi-representation strategy.

The implication of the triadic model of a multi-representation strategy is to understand or explain concepts that use interpretation reasoning and various forms of representation to learn new concepts together by expressing them in other ways.

One of the various types of learning environments is the natural environment, or more specifically called the local environment. The local environment can be defined with regard to all things natural such as geographical conditions, climate, air temperature, seasons, rainfall, 
flora (plants), fauna (animals), natural resources (water, forests, soil, rocks, etc.). The local environment is a marketing learning resource and media for students and can be optimized in the learning process to enrich the material and make the teaching process more varied and improve social skills in the surrounding community.

The use of the surrounding environment in the marketing learning process will be more meaningful because students are faced with actual events and make it an experience that enhances students' social skills. In utilizing the surrounding environment as a source and medium of learning. The presence of the media has important meaning. Because in this activity the ambiguity of the material delivered can be helped by presenting the media as an intermediary as a message distribution to achieve marketing learning objectives in improving students' social skills. In developing marketing learning media, teachers must be creative in designing, making, or organizing, and must also take initiatives to utilize the surrounding environment in teaching learning. In order to exploit local potential, it is necessary to try to improve the ability of teachers and be encouraged to become creative and professional teachers. Media in marketing learning in improving students' social skills can be used in stages:

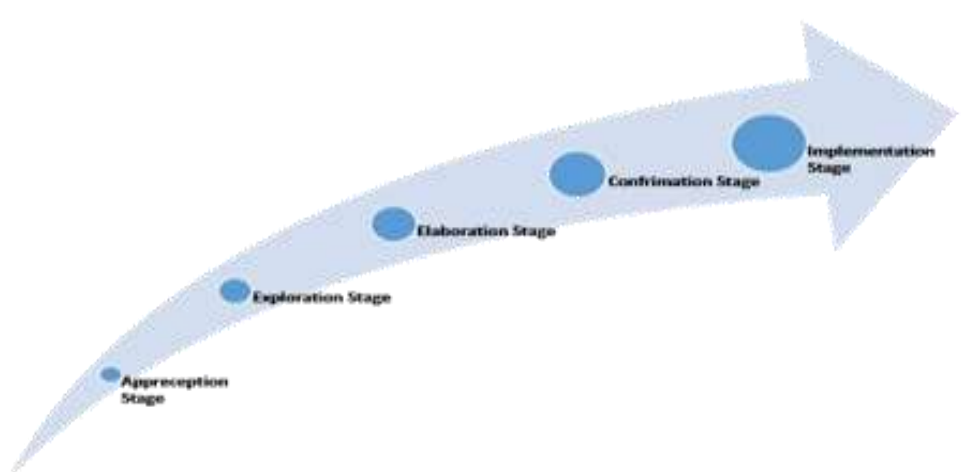

Fig. 2. Learning phase to improve community social skills.

The making of marketing learning media based on local marketing must consider the following criteria:

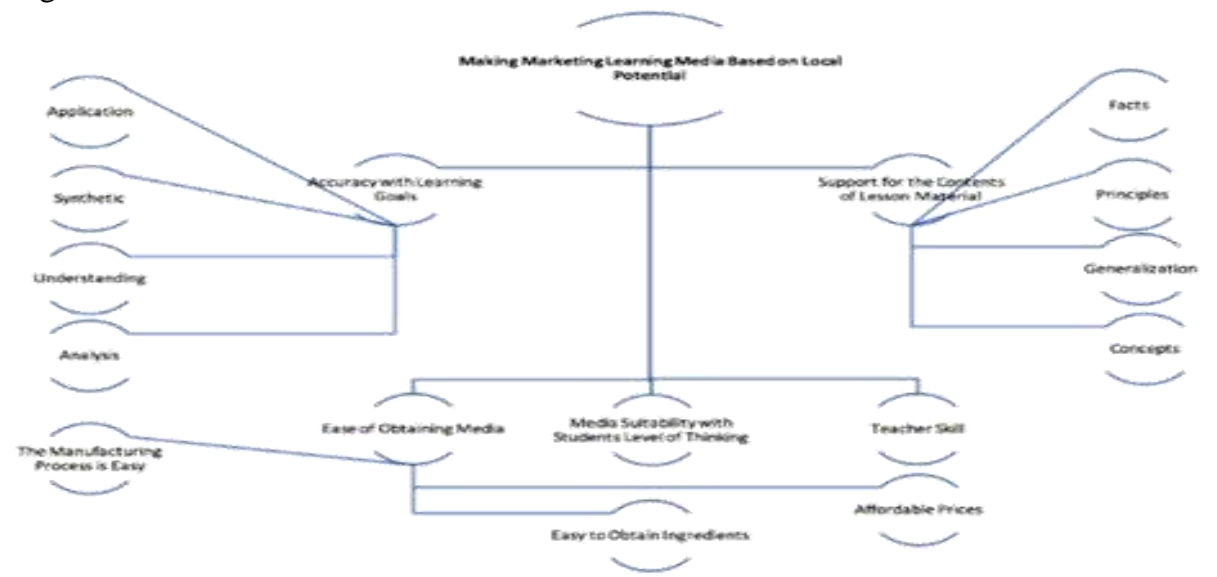

Fig. 3. Creating marketing learning media based on local potential. 
Steps to use local potential as a medium for social skills-based marketing learning: 1 . Making learning problems using nature as a problem. This can be done by: (a) Analysis of local potential by observing objects in the surrounding community and their symptoms, and identifying problems using a SWOT analysis that can be raised in learning. (b) Synchronize the results of analysis that is beneficial to the local with the applicable curriculum. For the sequence of steps (a) and (b) can (b) then (a) if you start looking for learning problems by observing the curriculum first and continue by choosing local potential that is suitable for use in studying the material contained in this basic competency. Formulate the learning objectives clearly, especially in the form of student behavior that can be observed and measured. Learning objectives can be in the form of factual info, principles and concepts, procedures, skills, and attitudes. 3. Determine learning activities carried out by the community by using learning media by using local potential around. 4. Determine the concepts that can be learned by using this local potential. 5. Determine the presentation or form of media packaging that increases the local potential around. Media forms can include mind mapping, film slides, slides, films, Student Worksheets. The form of media depends on the learning objectives to be achieved. Each type of media has the ability to achieve learning objectives, some are high, medium, and low.

\section{Conclusion}

From the results of the study it can be concluded that : (1) The development of learning models based on local potential at the center of teaching and learning activities has proven effective for the sustainability of programs that can improve social skills and income of learning citizens. Based on this, efforts must be made to disseminate the area in order to be able to apply the model at the center of other teaching and learning activities. (2) With marketing learning, it is hoped that learning at the center of teaching and learning activities will be sustainable by developing various types of programs, thereby increasing the income of learning citizens. (3) Need attention for the management of marketing learning based on local potential to improve social skills at the center of teaching and learning activities are; (a) in the planning stage it must involve the central management of teaching and learning activities, teachers / tutors and learning citizens to plan together: identify learning needs, utilize available potential, formulate goals, determine learning materials, determine learning methods, use available tools, determine time and market results. (b) Centered on student-centered learning so that participatory learning models are more dominantly followed by residents. (4) Coaching activities are carried out in accordance with the needs and problems associated with teachers and the learning community by increasing partnerships with various relevant parties and the material is adjusted to local potential in the community.

\section{References}

[1] A. F. Rodli, A. Prasnowo, M. B. N. Wajdi, and S. Sajiyo, "Building a Culture of Learning to Accelerate the Advancement of Higher Learning," in International Conference on Religion and Public Civilization (ICRPC 2018), 2019.

[2] R. Indonesia, "Undang-undang Republik Indonesia nomor 20 tahun 2003 tentang sistem pendidikan nasional," Jakarta Pemerintah Republik Indones., 2003.

[3] L. A. Pinzon-Salcedo and M. A. Torres-Cuello, "Community Operational Research: 
Developing a systemic peace education programme involving urban and rural communities in Colombia," Eur. J. Oper. Res., vol. 268, no. 3, pp. 946-959, 2018.

[4] M. Yasmin, F. Naseem, and I. C. Masso, "Teacher-directed learning to self-directed learning transition barriers in Pakistan,” Stud. Educ. Eval., vol. 61, pp. 34-40, 2019.

[5] A. Peña-Ayala and L. A. Cárdenas-Robledo, "A cybernetic method to regulate learning through learning strategies: A proactive and reactive mechanism applied in U-Learning settings," Comput. Human Behav., vol. 98, pp. 196-209, 2019.

[6] A. Rodli, "The Implementation of Icloud System Based on Knowledge Sharing at The University of Maarif Hasyim Latih Sidoarjo," J. Educ. Teach. Learn., vol. 2, no. 1, pp. 53-58, 2017.

[7] S. A. Ahmad, "Social Networking Sites Usage and Students' Attitudes Towards Social Behaviors and Academic Adjustment in Northern Nigerian Universities." Universiti Utara Malaysia, 2011.

[8] K. Chirumalla, P. Oghazi, and V. Parida, "Social media engagement strategy: Investigation of marketing and R\&D interfaces in manufacturing industry," Ind. Mark. Manag., vol. 74, pp. 138-149, 2018.

[9] J. McLean, M. Graham, S. Suchet-Pearson, H. Simon, J. Salt, and A. Parashar, "Decolonising strategies and neoliberal dilemmas in a tertiary institution: Nurturing care-full approaches in a blended learning environment," Geoforum, vol. 101, pp. 122-131, 2019.

[10] U. Zaman, Z. Jabbar, S. Nawaz, and M. Abbas, "Understanding the soft side of software projects: An empirical study on the interactive effects of social skills and political skills on complexity-performance relationship," Int. J. Proj. Manag., vol. 37, no. 3, pp. 444-460, 2019.

[11] A. F. Rodli, E. Boeriswati, M. A. Prasnowo, D. Pamungkas, and R. Nirwanasari, "Android-based games to detect history of radicalism," in Journal of Physics: Conference Series, 2019, vol. 1175, no. 1, p. 12026.

[12] A. F. Rodli, "Building Artificial University Model Based on National Ranking Parameters," in International Symposium on Social Sciences, Education, and Humanities (ISSEH 2018), 2019.

[13] R. Arbolino, T. Yigitcanlar, P. L'Abbate, and G. Ioppolo, "Effective growth policymaking: Estimating provincial territorial development potentials," Land use policy, vol. 86, pp. 313-321, 2019.

[14] A. Purwanto, J. Sušnik, F. X. Suryadi, and C. de Fraiture, "Determining strategies for water, energy, and food-related sectors in local economic development," Sustain. Prod. Consum., vol. 16, pp. 162-175, 2018.

[15] Y. Shi, Y. Mi, J. Li, and W. Liu, "Concurrent concept-cognitive learning model for classification,” Inf. Sci. (Ny)., vol. 496, pp. 65-81, 2019.

[16] T. Sunderland and T. Butterworth, "Meeting local economic decision-maker's demand for environmental evidence: The Local Environment and Economic Development (LEED) toolkit," Ecosyst. Serv., vol. 17, pp. 197-207, 2016.

[17] S. H. Saputro et al., "Utilization of Whatsapp Application as Communication Media in Language Teaching and Learning at FBS UWKS," in Journal of Physics: Conference Series, 2019, vol. 1175, no. 1, p. 12262.

[18] D. Bandung, "Metode Penelitian Pendidikan Pendekatan Kuantitatif, Kualitatif dan R \& D," Bandung Alf., 2013.

[19] S. Azwar, "Metode Penelitian; Penelitian Sebagai Kegiatan Ilmiah," Yogyakarta: Pustaka Belajar, 1999. 
[20] P. Sugiyono, "Metode Penelitian Kuantitatif, Kualitatif, dan R\&D," Metod. Penelit. Kuantitatif, Kualitatif, dan R\&D. Bandung CV Alf., 2010. 